\title{
Studies on the management and exploitation of aquatic weeds for manurial value for sustaining soil health
}

S. ANUSHMA AND B. APARNA

Received : 26.02.2016; Revised : 17.03.2016; Accepted : 13.04 .2016

MEMBERS OF RESEARCH FORUM:

Corresponding author :

S. ANUSHMA, Department of Soil Science and Agricultural Chemistry, College of Agriculture, Vellayani, THIRUVANANTHAPURAM (KERALA) INDIA

Co-authors :

B. APARNA, Department of Soil

Science and Agricultural Chemistry,

College of Agriculture, Vellayani, THIRUVANANTHAPURAM (KERALA) INDIA

\section{Summary}

The experiment was completed in three stages. Representative samples of water cabbage (Limnocharis flava), coir pith, water hyacinth (Eichhornia crassipes) and farm wastes (dried leaves and pseudostem of banana) were collected and analysed for bio-chemical composition. Then the four substrates were treated with four inoculants viz., Trichoderma reesei, Pleurotus sajor-caju, composting inoculums and commercial enzyme cocktail. The resultant composts were analyzed for the manurial value so as these weed plants and farm residues can be efficiently utilized for the preparation of composts which can induce the soil nutrient content and health. From the study water cabbage was the best substrate in terms of their chemical composition followed by water hyacinth.

Key words : Management, Exploitation, Aquatic weeds, Soil health

How to cite this article : Anushma, S. and Aparna, B. (2016).Studies on the management and exploitation of aquatic weeds for manurial value for sustaining soil health. Asian J. Soil Sci., 11 (1) : 20-28 : DOI : 10.15740/HAS/AJSS/11.1/20-28. 